REVIEW

\title{
Analysis of the Accounting Scientific Production Applied to Businesses and Economy of Scopus
}

\author{
Irene Buele Nugra ${ }^{1 *}$, Luisa Tahua ${ }^{1}$, Fabian Cuesta $^{1}$ \\ ${ }^{1}$ Universidad Politecnica Salesiana, Ecuador \\ *Corresponding author: Irene Buele Nugra: ibuele@ups.edu.ec
}

\section{OPEN ACCESS}

Citation: Nugra I.B., Tahua L., Cuesta F. (2020) Analysis of the Accounting Scientific Production Applied to Businesses and Economy of Scopus. Open Science Journal 5(2)

Received: $4^{\text {th }}$ March 2020

Accepted: $25^{\text {th }}$ May 2020

Published: $26^{\text {th }}$ June 2020

Copyright: (c) 2020 This is an open access article under the terms of the Creative Commons Attribution License, which permits unrestricted use, distribution, and reproduction in any medium, provided the original author and source are credited.

Funding: The author(s) received no specific funding for this work

Competing Interests: The author has declared that no competing interests exists.

\begin{abstract}
:
Due to the proliferation of scientific production, bibliometric science is used as a tool for the quantification, grouping and evolutionary evaluation of all documented information. The purpose of this research is to provide a detailed analysis of the composition of the Scopus platform, during the period 2012-2016, regarding publications related to Accounting. A relationship between qualitative variables of articles applied to companies and the economy is explained and analyzed. The results show a decrease in the amount of publications over the years of the study. The United Kingdom is exhibited as the country with the highest number of articles and an outstanding application of a theoretical, bibliographic and perceptions approach. Journals stipulate different approaches in their studies; however, General Accounting leads these approaches. Based on this information, further research on specific accounting application issues is recommended, not just related to general accounting, and that these publications are in English in line with global trends.
\end{abstract}

Keywords: Accounting, bibliometrics, general accounting, scientific production, Scopus.

\section{Introduction}

"Scientific knowledge transcends facts, discards facts, produces new facts, and explains them"(p. 11) [1]. From the 19th century onwards, the appreciation of the first explorations and investigative observations emerged. During that time there were hardships and lack of necessary materials and equipment for the elaboration and writing of new documents that would work as support for future 
studies [2]. This context led to the emergence of institutions dedicated to expanding scientific knowledge [3].

The socialist and cultural oppression in Europe opened evolutionary movements in the literary and investigative fields [4], giving rise to authors who migrated from this oppression and sought prominence in academic journals. Migrant authors promoted their knowledge and intellect in other countries causing a great advance in the investigative field [5].

With the birth of new scientists and new scientific ideas, it begins to collect documentation to generate more studies [3]. It is evident that science generates new information and when it is produced it becomes scientific research. In general, a study of this nature is reflected in a scientific article. Published articles suit, corner, and fulfill several needs; one of them is the academic aspect, in this area, a narrow view between scientific knowledge and science is presented [6]. Scientific evaluation emerged as Statistical Bibliography in this context. Later, a new term for this process of scientific quantification appeared, addressing the year of 1934, with the name by which it is identified until today, "bibliometrics" [7].

Bibliometrics is a discipline that allows the quantification of all academic published articles through the application of various statistical and mathematical methods and procedures, allowing the aggregation of criteria, tactics, patterns, guidelines, among others, of the scientific publications that have been disseminated in journals of global impact [8]. Depending on the scientific doctrine to which it is applied, the nature and field of study will be analyzed and studied, using as a guide the bibliometric laws and mathematical and statistical methods [9].

Indicators are the best instruments for the quantification and measurement of scientific production [10]. These indicators are diverse and work with qualitative and quantitative data according to the diversity, plurality and complexity of each work, focusing mainly on the criteria of the authors Pérez Reyes and Martínez Rodríguez [11]. Spanish authors, González, Moya and Hernández [12] have found and focused their study on a medical-scientific terminology with a social focus and focusing on indicators such as: production, consumption, circulation, dispersion and repercussion. On the other hand, the authors Maltrás, Quintanilla and Vidal [13] divide these indicators into production, quality and collaboration, coinciding with the previous authors, who are mainly concerned with quality to value the scientific production of science.

Currently, all universities worldwide are going through high evaluation regimes to accredit their educational activity. These accreditation processes are carried out through an appropriate classification and the corresponding position is defined when performing the assessment by checking whether each university complies with the requirements established by the evaluators, presenting themselves as a reference that accredits and testifies to their quality [14].

One of the most popular platforms worldwide, which serves to store scientific publications, is Scopus. This library externalizes many scientific publications by offering research with general approaches in distinctive areas [15]. Also the Institute for Scientific Information [ISI] is the entity in charge of issuing annually the factor of impact corresponding to the evaluation of scientific journals presented in the JCR (Journal Citation Reports) [16], being a very useful tool when evaluating the investigative significance and influence worldwide, it infers the number of bibliographic citations of other authors in its calculation [17].

With the examination and study of the articles, the most substantial aspects of what has been scientifically written on accounting topics will be presented. 
Hypotheses that contribute to the explanation of the qualities that intervene in the study of bibliometrics will be verified. It will serve as an instrument for the new generators of knowledge when reporting on detailed topics that have been written about and the aspects that need to be deepened.

\section{Methodology}

The article explores, with a qualitative approach, the publications referring to the accounting sciences applied to business and economy in the Scopus platform between 2012 and 2016 .

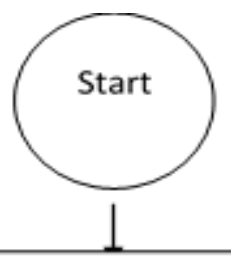

Search in Scopus with the word

"Accounting" in title

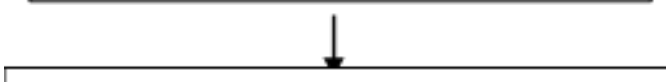

Filters application to select articles: areas of Business Administration and

Accounting and Economics, Econometrics and Finance, in Spanish, English, Portuguese.

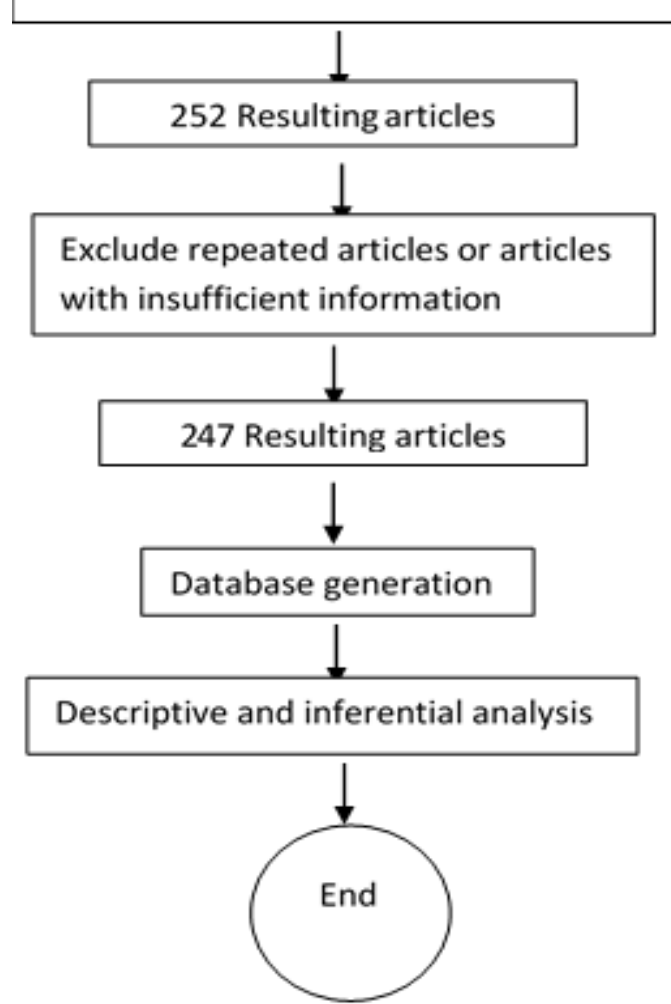

Figure 1. Flow diagram of the methodology used 
From Scopus' publications the articles will be studied, leaving aside press publications, reviews, session documents, editorials and notes. In order to obtain the information and to simplify the study, several filters were used: two of the ten areas presented by Scopus were used, these are: 1) Business Administration and Accounting, and 2) Economy, Econometrics and Finance. These areas were chosen because they are the most influential topics in accounting science [18], in articles in Spanish, English and Portuguese. Once the filters were applied, 252 results were obtained, working with 247 data, excluding journals with repeated statements or references with insufficient information to be included in the study.

The generable database includes variables such as: name of the published article, year of publication, writing language, type of accounting, scope, period of research, author or authors, country of origin of the first author, gender of the authors, name of the journal where the article was published, and the quartile to which it belongs, area of study, name of the promoter university or institution, country where the university is located, and ranking of the promoter institution.

The articles were further classified by approach and scope, as described in Tables 1 and 2 .

Table 1. Description of the approaches of the articles.

\begin{tabular}{|c|c|}
\hline Scope & Description \\
\hline Academic & $\begin{array}{l}\text { All documents containing interviews, questionnaires, examinations, } \\
\text { qualitative evaluations and perceptions of students of higher academic } \\
\text { institutions were categorized. }\end{array}$ \\
\hline Business & $\begin{array}{l}\text { Correspond to articles that applied studies to the employees of an } \\
\text { institution. Different accounting evaluations were used directed to: } \\
\text { accounting area, financial statements, growth indexes, financial valuations, } \\
\text { among others. }\end{array}$ \\
\hline Collective & $\begin{array}{l}\text { This area relates the actions of several authors or organizations in the } \\
\text { preparation of the article. }\end{array}$ \\
\hline Cultural & This group classifies the articles that have studied social chances over time. \\
\hline International & Articles that have compared different situations between countries. \\
\hline Governmental & $\begin{array}{l}\text { Articles that analyze laws, policies, regimes, decrees, impositions of } \\
\text { imposed politicians and their affectations and influences with the } \\
\text { accounting development. }\end{array}$ \\
\hline National & Studies applied to the whole country or exclusively to one or several cities. \\
\hline General & $\begin{array}{l}\text { All the articles that do not have any specification of the place where the } \\
\text { study was applied or the territorial limitations where they were carried out } \\
\text { are detailed within this scope. }\end{array}$ \\
\hline Historical & $\begin{array}{l}\text { Articles that were responsible for the collection of information over the } \\
\text { years, evolution and effects at present. }\end{array}$ \\
\hline Financial & Articles regarding the financial evolution. \\
\hline
\end{tabular}

Source: Done by the author based on the Scopus database 2012-2016. 
In order to determine the focus of the articles, 19 different criteria were proposed; they are described below:

Table 2. Description of the scope of the investigation

\begin{tabular}{ll}
\hline \multicolumn{1}{c}{ Approach } & \multicolumn{1}{c}{ Description } \\
\hline $\begin{array}{l}\text { Outsourcing } \\
\text { Alliance }\end{array}$ & $\begin{array}{l}\text { This group includes the studies applied to companies that made their } \\
\text { organization available to another. }\end{array}$ \\
\hline $\begin{array}{l}\text { Bibliometric } \\
\text { analysis }\end{array}$ & Articles that summarize academic research by other authors. \\
\hline $\begin{array}{l}\text { Theoretical and } \\
\text { bibliographic } \\
\text { analysis. }\end{array}$ & $\begin{array}{l}\text { It corresponds to the articles that detail only particularities such as: } \\
\text { history environments, descriptions of the authors, and important study } \\
\text { data. }\end{array}$ \\
\hline $\begin{array}{l}\text { Academic } \\
\text { applications }\end{array}$ & It includes articles related to academic procedures or assessments. \\
\hline
\end{tabular}

Organizational behavior

Studies based on the activities and attitudes of employees and employers within the company in to prove if this helps business performance.

For this category, all the articles that have norms, policies, instructions,

Environmental guidelines and precepts, among others, were included, focused mainly on biodiversity and its adaptability to the environment and the participants who intervene, studying the behaviors that reside in their actions.

It refers to studies focused on the organizational aspect that is applied in Accounting Ethics the company and how the guiding principles influence the way by which companies are related to employees.

\begin{tabular}{ll}
\hline $\begin{array}{l}\text { Accounting } \\
\text { evaluation }\end{array}$ & It is focused on the analysis of financial management. \\
\hline $\begin{array}{l}\text { Budgetary } \\
\text { management }\end{array}$ & $\begin{array}{l}\text { Articles referring to the budget procedures, audits, and analysis are } \\
\text { included in these criteria. }\end{array}$ \\
\hline $\begin{array}{ll}\text { Accounting tools } \\
\text { Articles that refer to instruments used for the development of research } \\
\text { and studies. }\end{array}$ \\
$\begin{array}{ll}\text { Government } \\
\text { taxation }\end{array}$ & $\begin{array}{l}\text { Referring to the accounting policies that the government inflicts on its } \\
\text { pimitations of } \\
\text { accounting } \\
\text { regulations }\end{array}$ \\
\hline
\end{tabular}

Logistics

Accounting detail of all the required processes for monitoring products, predicting the collection and evaluation of data in a statistical way.

Accounting

Perceptions

These are all the opinions and judgments that participants have in order to identify different variables, attitudes and opinions within various accounting topics.

Reengineering of Articles, which help in the implementation of a new accounting system. accounting

processes 
Accounting risk These are the articles that study the instability of a company through accounting standards.

Accounting For this group all the various systematic mechanisms that facilitate the information information process for decision making were chosen.

system

Drop-shipping All articles that consider the of the accounting of a sale. transactions

Accounting Articles referring to the evaluation, identification and delegation of the treatment accounts at the time of accounting.

Source: Done by the author based on the Scopus database 2012-2016.

With the tabulated information the author proceeded to extract the frequency, performed variable crossings and hypothesis tests by the Pearson chisquare method, mainly done with IBM SPSS Statistics v24 software.

\section{Results}

The results are divided into two sections: a) Descriptive analysis and b) Inferential Analysis.

A) Descriptive Analysis

Exploratory studies were used on the validity of an event and its respective interpretation is exposed with the use of criteria that support it [19].

Table 3. Participation of journals by country and year

\begin{tabular}{|c|c|c|c|c|c|c|}
\hline \multirow[b]{2}{*}{ Country } & \multicolumn{5}{|c|}{ Year of Publication } & \multirow[b]{2}{*}{$\begin{array}{c}\text { General } \\
\text { Total }\end{array}$} \\
\hline & 2012 & 2013 & 2014 & 2015 & 2016 & \\
\hline United Kingdom & $15,97 \%$ & $12,50 \%$ & $5,56 \%$ & $5,56 \%$ & $5,56 \%$ & $45,14 \%$ \\
\hline \multicolumn{7}{|l|}{ Accounting, Auditing and } \\
\hline Accountability Journal & $7,64 \%$ & $4,17 \%$ & $2,08 \%$ & $2,78 \%$ & $2,78 \%$ & $19,44 \%$ \\
\hline Accounting Education & $0,69 \%$ & $1,39 \%$ & $1,39 \%$ & $2,78 \%$ & $1,39 \%$ & $7,64 \%$ \\
\hline United States & $5,56 \%$ & $4,17 \%$ & $3,47 \%$ & $3,47 \%$ & $4,17 \%$ & $20,83 \%$ \\
\hline Accounting History & $3,47 \%$ & $2,78 \%$ & & & $2,08 \%$ & $8,33 \%$ \\
\hline Critical Perspectives on Accounting & & & $2,78 \%$ & $1,39 \%$ & $2,08 \%$ & $6,25 \%$ \\
\hline Ukraine & $1,39 \%$ & $2,78 \%$ & $4,17 \%$ & $5,56 \%$ & $2,78 \%$ & $16,67 \%$ \\
\hline Actual Problems of Economics & $1,39 \%$ & $1,39 \%$ & $2,08 \%$ & $1,39 \%$ & $0,69 \%$ & $6,94 \%$ \\
\hline Economic Annals-XXI & & & $1,39 \%$ & $2,78 \%$ & $0,69 \%$ & $4,86 \%$ \\
\hline Romania & & $1,39 \%$ & $1,39 \%$ & $1,39 \%$ & $2,08 \%$ & $6,25 \%$ \\
\hline Journal of Applied Economic Sciences & & $0,69 \%$ & $0,69 \%$ & $0,69 \%$ & $0,69 \%$ & $2,78 \%$ \\
\hline Quality - Access to Success & & $0,69 \%$ & $0,69 \%$ & & $0,69 \%$ & $2,08 \%$ \\
\hline Netherlands & $1,39 \%$ & & $0,69 \%$ & $2,78 \%$ & $0,69 \%$ & $5,56 \%$ \\
\hline Journal of Business Ethics & & & & $0,69 \%$ & $0,69 \%$ & $1,39 \%$ \\
\hline Journal of Cleaner Production & $0,69 \%$ & & & $0,69 \%$ & & $1,39 \%$ \\
\hline Venezuela & $0,69 \%$ & & & $2,08 \%$ & $2,78 \%$ & $5,56 \%$ \\
\hline
\end{tabular}




\begin{tabular}{|c|c|c|c|}
\hline Espacios & $0,69 \%$ & $2,08 \%$ & $4,86 \%$ \\
\hline European Research Studies Journal & & $0,69 \%$ & $0,69 \%$ \\
\hline
\end{tabular}

Source: Done by the author based on the Scopus database 2012-2016.

Table 3 shows the top 5 countries that publish accounting topics and includes the 2 most representative journals. The publications have a close relationship with the place of dissemination, the largest publications are those made in developed countries [20]. United Kingdom and the United States are mentioned, among the 18 countries with the highest income, determined by their high nominal GDP per capita, and expressed in the list presented by the World Bank [21]. These countries have high and better resources for investment in universities and research, which allows them to achieve the best rankings in the Webometrics classification, United States has the best university and the first in the United Kingdom occupies the seventh position, according to this indicator [22]. These publications also had the best tools and intellectual resources for the development of a greater diversity of valuable topics for scientific and research advance, which contribute not only to the country, but also to the development of knowledge in a universal sense [23].

Table 4. Number of publications according to the type of accounting, classified by year

\begin{tabular}{|c|c|c|c|c|c|c|}
\hline \multirow{2}{*}{ Type of accounting } & \multicolumn{5}{|c|}{ Year of publication } & \multirow{2}{*}{$\begin{array}{l}\text { General } \\
\text { Total }\end{array}$} \\
\hline & 2012 & 2013 & 2014 & 2015 & 2016 & \\
\hline General Accounting & $12.55 \%$ & $12.55 \%$ & $6.88 \%$ & $17.00 \%$ & $14.17 \%$ & $63.15 \%$ \\
\hline Financial Accounting & $2.83 \%$ & $3.64 \%$ & $3.24 \%$ & $1.21 \%$ & $0.81 \%$ & $11.73 \%$ \\
\hline Cost Accounting & $0.40 \%$ & $0.40 \%$ & $2.83 \%$ & $0.81 \%$ & $0.81 \%$ & $5.25 \%$ \\
\hline Management Accounting & $0.81 \%$ & $2.83 \%$ & $0.81 \%$ & & $0.81 \%$ & $5.26 \%$ \\
\hline Government Accounting & $3.24 \%$ & & $0.40 \%$ & & $0.81 \%$ & $4.45 \%$ \\
\hline Social Accounting & $0.40 \%$ & & & $0.81 \%$ & $1.62 \%$ & $2.83 \%$ \\
\hline Managerial Accounting & & $0.40 \%$ & $0.81 \%$ & $0.40 \%$ & $0.40 \%$ & $2.01 \%$ \\
\hline Environmental Accounting & $0.40 \%$ & & $0.40 \%$ & $0.81 \%$ & & $1.61 \%$ \\
\hline International Accounting & $1.21 \%$ & & & & & $1.21 \%$ \\
\hline Information Systems Accounting & & & & $0.40 \%$ & $0.40 \%$ & $0.80 \%$ \\
\hline Advanced Accounting & & & & & $0.40 \%$ & $0.40 \%$ \\
\hline Intellectual capital Accounting & $0.40 \%$ & & & & & $0.40 \%$ \\
\hline Biodiversity Accounting & & $0.40 \%$ & & & & $0.40 \%$ \\
\hline Tax Accounting & & $0.40 \%$ & & & & $0.40 \%$ \\
\hline General Total & $22.24 \%$ & $20.62 \%$ & $15.37 \%$ & $21.44 \%$ & $20.23 \%$ & $99.9 \%$ \\
\hline
\end{tabular}

Source: Done by the author based on the Scopus database 2012-2016.

Table 4 shows that it has been written about 14 types of accounting for 5 years. The results show that a greater percentage has been written about General Accounting in 2015. Within this type of accounting, articles dealing with the application of accounting programs, resolution of conflicts with the application of general accounting methods, accounting implementation to institutions, and interviews and perceptions of people as members of a business organization can be identified. 
Table 5. Number of publications according to the approach and the journal quartile

\begin{tabular}{|c|c|c|c|c|c|}
\hline \multirow{2}{*}{ Approach } & \multicolumn{4}{|c|}{ Quartile } & \multirow{2}{*}{ Total } \\
\hline & Q1 & Q2 & Q3 & Q4 & \\
\hline Theoretical and bibliographic analysis & $9.31 \%$ & $4.05 \%$ & $4.86 \%$ & $1.21 \%$ & $19.43 \%$ \\
\hline Accounting perceptions & $3.24 \%$ & $2.43 \%$ & $2.83 \%$ & $3.24 \%$ & $11.74 \%$ \\
\hline Accounting tools & $1.62 \%$ & $3.64 \%$ & $2.83 \%$ & $1.62 \%$ & $9.71 \%$ \\
\hline Accounting information system & $0.81 \%$ & $2.43 \%$ & $2.02 \%$ & $2.43 \%$ & $7.69 \%$ \\
\hline Bibliometric analysis & $4.05 \%$ & $0.40 \%$ & $1.21 \%$ & $0.81 \%$ & $6.47 \%$ \\
\hline Academic applications & $0.81 \%$ & $2.83 \%$ & $2.43 \%$ & $0.40 \%$ & $6.47 \%$ \\
\hline Limitations of accounting regulations & $0.40 \%$ & $0.81 \%$ & $2.43 \%$ & $1.21 \%$ & $4.85 \%$ \\
\hline Organizational behavior & $2.02 \%$ & & $1.21 \%$ & $0.81 \%$ & $4.04 \%$ \\
\hline Accounting evaluation & $1.21 \%$ & $0.81 \%$ & $1.21 \%$ & $0.81 \%$ & $4.04 \%$ \\
\hline Logistics & $0.81 \%$ & $1.21 \%$ & $1.62 \%$ & $0.40 \%$ & $4.04 \%$ \\
\hline Environmental guidelines & $2.83 \%$ & $0.40 \%$ & $0.40 \%$ & & $3.63 \%$ \\
\hline Budgetary management & & $0.81 \%$ & $1.21 \%$ & $1.62 \%$ & $3.64 \%$ \\
\hline Accounting treatment & $0.40 \%$ & $0.81 \%$ & $2.02 \%$ & & $3.23 \%$ \\
\hline Accounting Risk & $0.81 \%$ & & $2.02 \%$ & & $2.83 \%$ \\
\hline Accounting Ethics & $1.21 \%$ & $0.40 \%$ & & $0.81 \%$ & $2.42 \%$ \\
\hline Government Imposition & $2.02 \%$ & & & & $2.02 \%$ \\
\hline Accounting Process Reengineering & $1.21 \%$ & & $0.40 \%$ & & $1.61 \%$ \\
\hline Outsourcing Alliance & $0.40 \%$ & & & $0.40 \%$ & $0.80 \%$ \\
\hline Drop-shipping Transactions & $0.40 \%$ & & $0.40 \%$ & & $0.80 \%$ \\
\hline Academic & $0.40 \%$ & & & & $0.40 \%$ \\
\hline General Total & $33.96 \%$ & $21.03 \%$ & $29.10 \%$ & $15.77 \%$ & $99.86 \%$ \\
\hline
\end{tabular}

Source: Done by the author based on the Scopus database 2012-2016.

These results illustrate 20 approaches to articles published according to their location in quartiles. Benavent, Valderrama, Castellano, Simó Meléndez, and Navarro Molina [24] state that a quartile gives authors the advantage of choosing and verifying the quality and position of a journal. There are different criteria for the division of these 4 positions and it also depends on the place of origin and the diffusion of information that the publication contributes in universal terms [25]. Table 5 reveals two approaches with more published articles: Theoretical and bibliographic analysis, and Accounting Perceptions, which have the largest number of articles published in journals defined in the first quartile (Q1). It can be highlighted that the most important journals are supported by prestigious institutions, which allow them to present higher quality documents, providing important contributions for future research [26]. 
Table 6. Number of publications according to the type of accounting, depending on the journal

\begin{tabular}{|c|c|c|c|c|c|}
\hline \multirow{2}{*}{ Type of Accounting } & \multicolumn{4}{|c|}{ Quartile } & \multirow{2}{*}{ Total } \\
\hline & Q1 & Q2 & Q3 & $\mathrm{Q} 4$ & \\
\hline General Accounting & $41,03 \%$ & $8,97 \%$ & $0,00 \%$ & $7,69 \%$ & $57,69 \%$ \\
\hline Accounting, Auditing and Accountability Journal & $26,92 \%$ & & & & $26,92 \%$ \\
\hline Accounting Education & & $8,97 \%$ & & & $8,97 \%$ \\
\hline Financial Accounting & $2,56 \%$ & $6,41 \%$ & $5,13 \%$ & & $14,10 \%$ \\
\hline Accounting Education & & $5,13 \%$ & & & $5,13 \%$ \\
\hline Economic Annals-XXI & & & $2,56 \%$ & & $2,56 \%$ \\
\hline Government Accounting & $6,41 \%$ & $2,56 \%$ & $2,56 \%$ & & $11,54 \%$ \\
\hline Accounting History & $3,85 \%$ & & & & $3,85 \%$ \\
\hline Journal of Accounting and Organizational Change & & & $2,56 \%$ & & $2,56 \%$ \\
\hline Social Accounting & $7,69 \%$ & & & $1,28 \%$ & $8,97 \%$ \\
\hline Accounting, Auditing and Accountability Journal & $3,85 \%$ & & & & $2,56 \%$ \\
\hline Accounting, Organizations and Society & $1,28 \%$ & & & & $1,28 \%$ \\
\hline Cost Accounting & $1,28 \%$ & $1,28 \%$ & $1,28 \%$ & $3,85 \%$ & $7,69 \%$ \\
\hline Actual Problems of Economics & & & & $2,56 \%$ & $2,56 \%$ \\
\hline International Economic Society & & & & $1,28 \%$ & $1,28 \%$ \\
\hline
\end{tabular}

Source: Done by the author based on the Scopus database 2012-2016.

Table 6 shows 5 types of accounting and includes the 2 most representative journals. Most of the journals expressed in Table 6 publish socio-economic, political, and financial issues related to accounting education [27], including the publication of perceptions of managers and administrators with the purpose of promoting ideas that serve as instrument for new writers [28]. There is a high diffusion of published articles regarding General Accounting and Quartile Q1.

B) Inferential analysis

The sample was analyzed using the statistical program SPSS v24, that allows describing the variables to be used and detecting possible relationships between them.

Hypothesis 1: research scope - first author gender relationship

Ho: Research scope is independent of the author gender.

H1: Research scope depends on the author's gender.

Level of significance $=0.05(95 \%)$. 


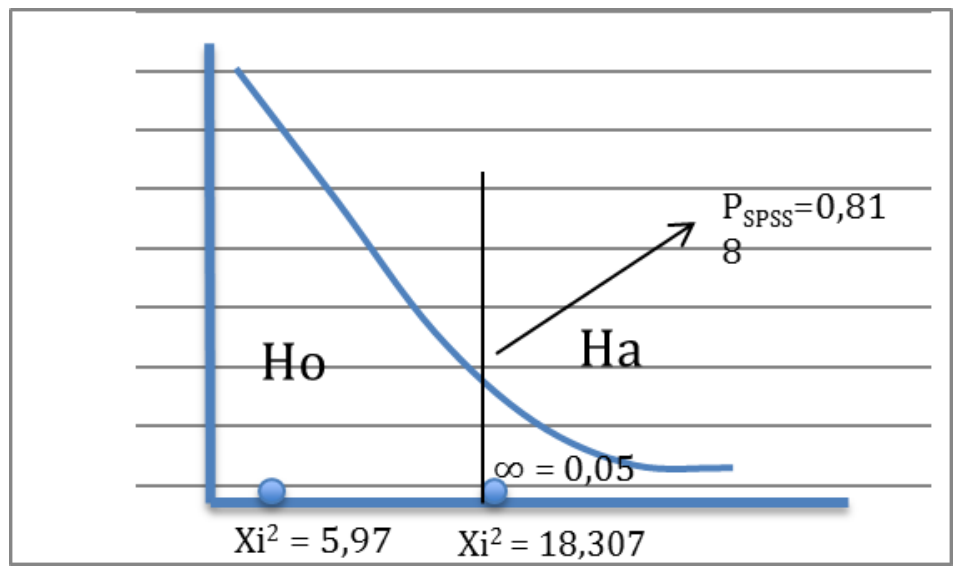

Figure 1. Gaussian Curve

Source: Done by the author based on the results provided by SPSS v24.

For the development of this hypothesis, 10 areas of research were presented that show in which field the study was carried out. Also, it was classified into two types of gender (male and female). When comparing the variables in the SPSS v24, it can be seen in Figure 1 that the value of $\mathrm{P}=0.818$ is higher than the level of significance of 0.05 . Therefore, it is concluded that the null hypothesis is true, which defines that the research scope of the articles is independent of the gender of the first author. The Academic, Business and General scopes were written by both men and women. The General scope was written on a $12.70 \%$ by men and $9.35 \%$ by women. In the Academic field, it is observed an $11.82 \%$ of male writers and an $8.99 \%$ of female writers in their articles.

Hypothesis 2: research scope - journal's country

Ho: Research scope is independent from the journal's country.

H1: Research scope depends on the journal's country.

Level of significance $=0.05(95 \%)$.

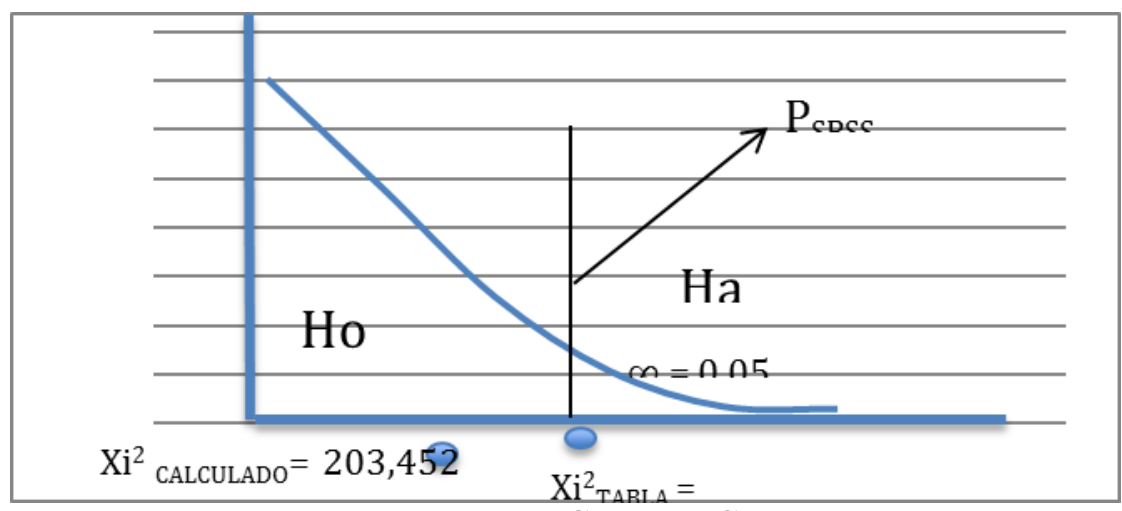

Figure 2. Gaussian Curve

Source: Done by the author based on the results provided by SPSS v24.

The 10 items raised in the research field and the countries in which the academic articles were carried out were used for the development of this hypothesis. Being the value of $\mathrm{P}=0.111$ higher than the level of significance of 0.05 , it is concluded that the null hypothesis is true and defines that the research scope of the articles is independent of the country of the journal. This case shows that the countries with the largest hoarding of publications on the Scopus 
platform are the United Kingdom and the United States. It is illustrated that the United Kingdom presents 125 articles focusing mainly on general, academic and cultural studies. A similar case can be found with the United States, which shows a total of 48 publications, where the main fields are the same as those in the United Kingdom.

Hypothesis 3. approach - type of accounting

Ho: The approach of the investigation is independent of the type of accounting.

H1: The approach of the investigation depends on the type of accounting.

Level of significance $=0.05(95 \%)$.

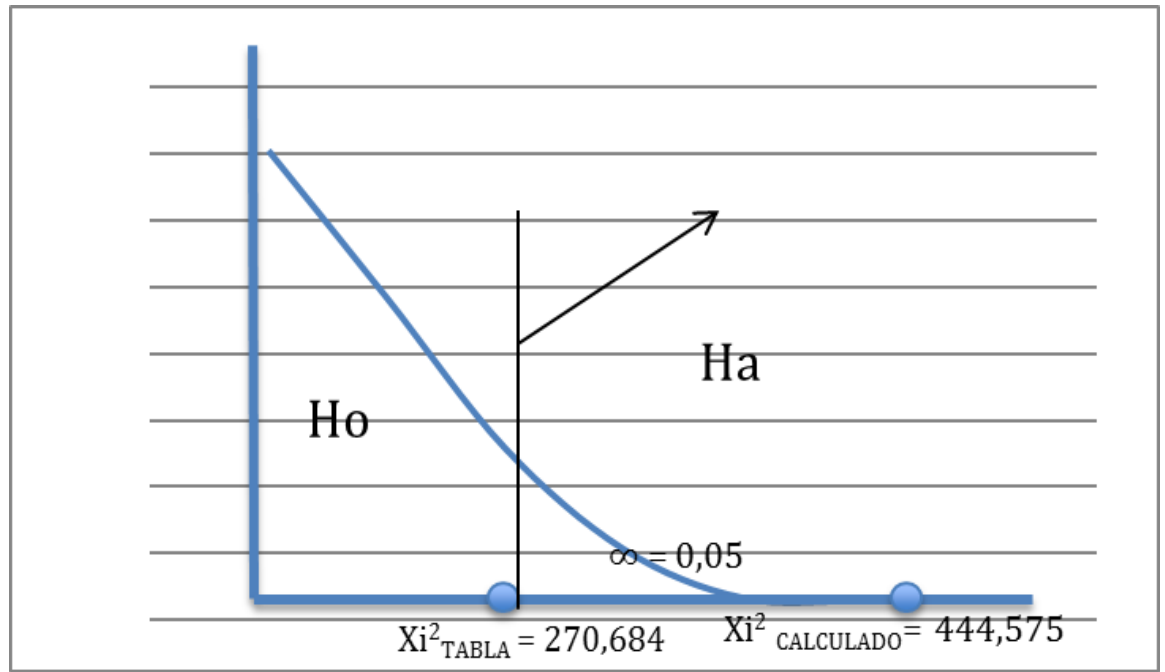

Figure 3. Gaussian Curve

Source: Done by the author based on the results provided by SPSS v24

This hypothesis is formulated with the use of 19 approaches and 14 types of accounting. When performing this procedure with a level of significance of 0.05 , the null hypothesis is rejected, and the alternative hypothesis is accepted, showing the existence of a relationship between the article's approach and the type of accounting; where the probability is 0.00 , which shows it is lower than the error level. A $19.43 \%$ of publications regarding the approach defined as theoretical and bibliographic analysis show a $11.74 \%$ that corresponds to accounting perceptions and a $7.69 \%$ correspond to Accounting Information Systems. In addition to that, all the mentioned approaches have publications made about General Accounting with a total of $15.79 \%, 10.12 \%$ and $4.05 \%$ correspondingly, being this accounting type the most widely used, as it represents a $63.16 \%$ of the total amount of the publications. This study, which was conducted in the SPSS shows that there exists a relationship between the approach and the type of accounting.

Hypothesis 4. use of central tendency statistics: mode

Ho: Q1 is the quartile most frequently used in this study.

H1: Q1 is the quartile used with less frequency in this study. 


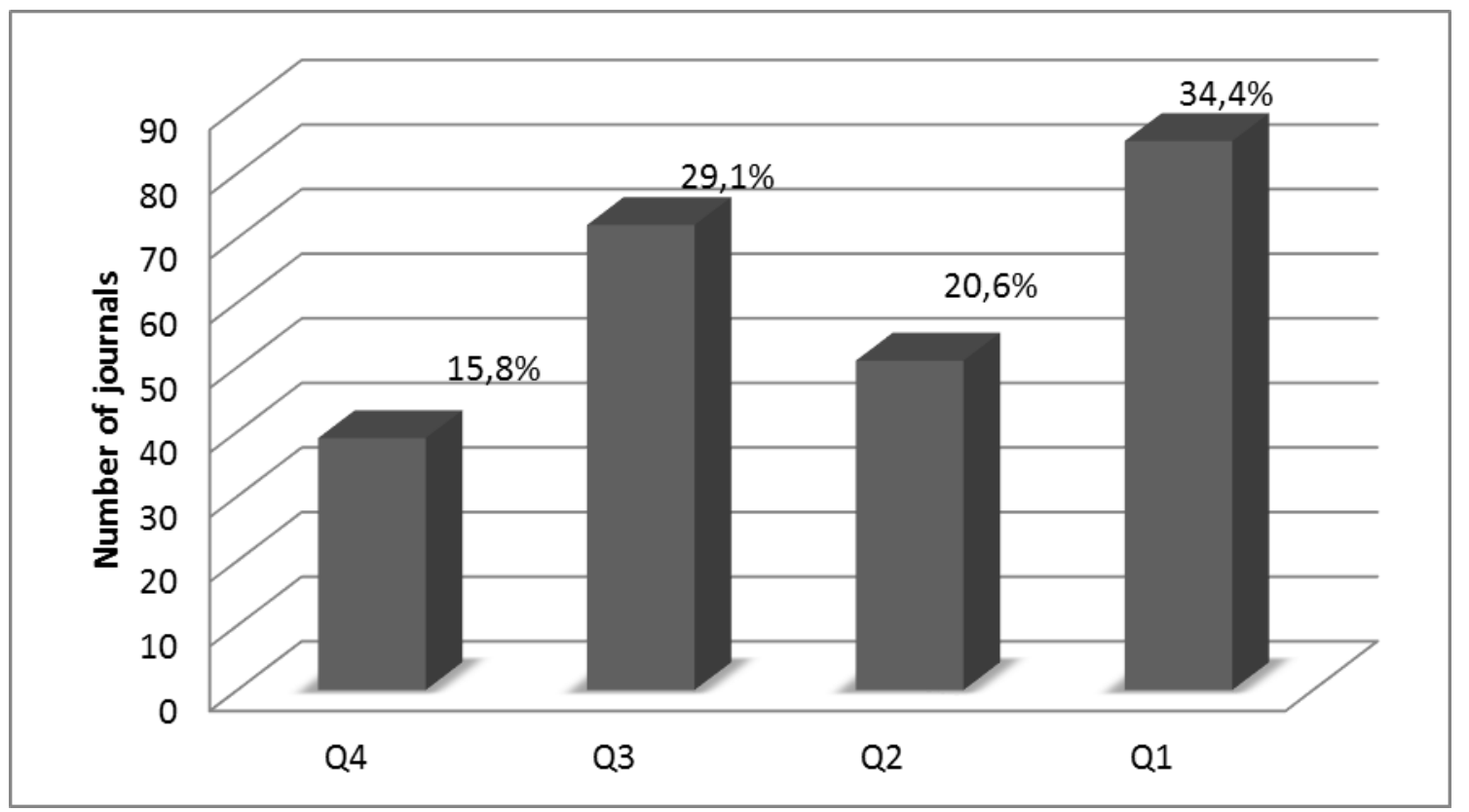

Figure 4. Position of the journal's quartile.

Source: Done by the author based on the results provided by SPSS v24.

In this hypothesis, the quartile of journals is used. It has been classified into 4 variables that show the positioning of the journals. When tabulating the information, it is observed that $34.4 \%$ of the journals are in quartile 1 , being this the largest number in this position. Therefore, the null hypothesis is demonstrated to be true, which states that the Q1 is the most used quartile within the quartiles of the journal. Coming back to the hypothesis established at the beginning of this study, it is now possible to affirm that the authors who publish more articles in this kind of journals have a better prestige and quality.

\section{Discussion}

In a world of vertiginous advances, globalization of information has allowed greater access to research that has revolutionized different concepts, theories, methods and models of scientific accounting production applied to business and economics. This has provided a reference framework that allows research in the knowledge society to have a broader purpose such as inducing people to reflect more deeply on the importance and role of accounting research in the life of societies, organizations and people. Information plays a preponderant role due to its transcendental importance in the development of knowledge. It must have validation through the application of a scientific method that allows creating the conditions so that obtained conclusions are based on evidence and not on assumptions or apparent knowledge. In this regard, bibliometrics provides a qualitative analysis of academic literature [29].

In 2012 publications reached a $22.27 \%$ while in 2016 they reached a $20.24 \%$, which shows a decrease of $2.02 \%$. This reflects an average variation of $1.42 \%$, which is closely related to the place of dissemination, where most of publications are those generally made in developed countries (the United States with $12 \%$ and the United Kingdom with 15\%). Developing countries depend on the science produced in first world countries, they should protect their resources, protected 
by the precepts of endogenous and sustainable development, and resort to knowledge of different types [30]. Topics related to general accounting cover $63.16 \%$ of the total percentage of publications, where its highest quartile (Q1) has a theoretical and bibliographic approach. Journals tend to publish mostly socioeconomic, political, and financial issues aligned with accounting education. On the other hand, the remaining three quartiles cover $66 \%$ of the publications [8]. Male researchers reached a $53.38 \%$ of publications, concluding in addition that women maintain an important participation in publications, reaching $46.62 \%$. This shows that there is gender equality in the publication of scientific journals.

Hypotheses point out that the author's gender is independent of the research scope and that a country is not focused on writing about a specific scope. They also show that the research approach does not have a direct relationship with the type of accounting and that most of articles that have been written about accounting issues were published in a Q1 journal.

\section{Conclusions}

Scientific production related to Accounting in the Scopus database did not grow rapidly between 2012 and 2016. It was observed that developed countries such as the United States and the United Kingdom predominate with respect to accounting research, mainly referring to general accounting with a review approach theoretical and bibliographic. Gender equality was fulfilled, no significant difference was observed between male and female authors.

The analysis of the relationships between variables also showed that the research approach does not have a direct relationship with the type of accounting and that most of the articles that have been written on accounting issues were published in a high-impact journal (Q1).

\section{References:}

1.Bunge, M 1959. La ciencia, su método y su filosofía. Sudamericana.

2.González, J. 2013 (mayo). Vicalvaradas. Available in https://vicalvaradas.wordpress.com/2013/05/10/historia-de-la-investigacion/

3.Ramos, J 2003. Desencuentros de la modernidad en América latina, literatura y política en el siglo XIX. $1^{\mathrm{O}}$ edición. Chile: Cuarto propio.

4.Tuirán, R 2009. Fuga de cerebros, movilidad académica, redes científicasRodolfo Tuirán. $1^{\mathrm{a}}$ edición. Editado por: Cinvestav. México, México.

5.Brandi, MC 2006. La historia del brain drain. Revista iberoamericana de ciencia tecnología y sociedad $3(7)$.

6.Campanario, JM 2004. Algunas posibilidades del artículo de investigación como recurso didáctico orientado a cuestionar ideas inadecuadas sobre la ciencia. Enseñanza de las ciencias 22 (3).

7.Carrizo, G 1969. Hacia un concepto de bibliometría. Journal of Documentation 25 (4).

8.Camps, D 2008. Limitaciones de los indicadores bibliométricos en la evaluación de la actividad cientifica biomédica.

9.Barba, M 2003. Los indicadores bibliométricos: fundamentos y aplicaciòn al anàlisis de la ciencia. Editado por Gijón. TREA.

10.Sancho, R 1990. Indicadores bibliométricos utilizados en la evaluación de la ciencia y la tecnología. Revista Española de Documentación Científica 13 (3).

11.Pérez Reyes, GA \& Martínez Rodríguez, A 2014. La ciencia como empresa social: su evaluación desde la bibliometría, editato po JS Aldana. 55 Edición.

12.González, JM, Moya, \& Hernández, M 1997. Indicadores bibliométricos: Características y limitaciones en el análisis de la actividad científica. Anales españoles de pediatria 47 (3).

13.Maltrás, B, Quintanilla, MA \& Vidal, J 1998. Indicadores bibliométricos en la evaluación de la investigación. Revista de Educaciòn 315. 
14.Díaz Barriga, Á 2009. La evaluación universitaria en el contexto del pensamiento neoliberal. JSTOR .

15.Relx Group 2018. Scopus. Available in https://www.elsevier.com/americalatina/es/scopus

16.Pacheco, C 2012. Factor de impacto. Revista electrónica cintífica y académica de clínica Alemana.

17.Téllez Zenteno, JF, Morales Buenrostro, LE \& Estañol, E 2007. Análisis del factor de impacto de las revistas científicas latinoamericanas. Revista médica de Chile .

18.Amat, O 2012. Contabilidad y finanzas para Dummies. 1a edición. Barcelona: Wiley Publishing Inc.

19.Etxeberria M, J \& Tejedor TJ 2005. Análisis descriptivo de datos en educación. Madrid: La Muralla.

20.Schkolnik, M, Araos, C \& Machado, F 2005. Certificaciòn por competencias como parte del sistema de protección social: la experiencia de países desarrollados y lineamientos para América Latina. Santiago de Chile, Chile: Naciones Unidas.

21.Mundial, B 2017. Resumen del año 2017 en 12 gráficos. 15 de Diciembre.

22.Björneborn, L \& Ingwersen, P 2004. Hacia un marco básico para webometrics. Revista de la asociación de ciencia y tecnología de la información 55 (14).

23.Torres, O \& Pau, B 2011. Acceso abierto a la producción científica de América Latina y el Caribe: Identification of main institutions for regional integration strategies. Revista iberoamericana de ciencia tecnología y sociedad. 6 (18).

24.Benavent, RA, Valderrama, JC, Castellano, M, Simó Meléndez, R \& Navarro Molina, C 2004. Factor de impacto de las revistas médicas españolas. Elsevier 123 (18).

25.Buela Casal, G 2003. Evaluación de la calidad de los artículos y de las revistas científicas: Propuesta del factor de impacto ponderado y de un índice de calidad. Revistas Científicas de América Latina y el Caribe, España y Portugal 15.

26.Patalano, M 2008. Las publicaciones del campo científico: las revistas académicas de América latin. Anales de documentación 8 .

27.Journal Citation Reports 2016. Available in Emerald Publishing: http://www.emeraldgrouppublishing.com/aaaj.htm

28.Taylor y Francis Group 2018. Taylor y Francis Online. Available in Educación Contable: https://www.tandfonline.com/action/journalInformation?show=aimsScope\&journalCode=raed2 0

29.Hulme, EW 1923. Statical bibliography in relation on the growth of modern civilization. Londres.

30.Guilherme, Ó., \& Arrechavaleta, N. (2017). Financing, science, technology and innovation and higher education in the developing countries. Revista Cubana de Educación Superior, 36(3), 419. Available in http://scielo.sld.cu/pdf/rces/v36n3/rces01317.pdf 